\title{
KUALITAS LAPORAN KEUANGAN PERUSAHAAN PUBLIK DI INDONESIA
}

\author{
Restiana Eka Febrita \\ restianaekafebrita@gmail.com \\ Universitas Kristen Satya Wacana, Indonesia \\ Ari Budi Kristanto \\ ari.kristanto@staff.uksw.ac.id \\ Universitas Kristen Satya Wacana, Indonesia
}

\begin{abstract}
ABSTRAK
Tujuan dari penelitian ini adalah untuk melihat bagaimana kualitas laporan keuangan di Indonesia. Kualitas laporan keuangan dalam penelitian ini kemudian dianalisis berdasarkan ukuran perusahaan dan kelompok industrinya. Penelitian berfokus pada perusahaan yang terdaftar di Bursa Efek Indonesia kecuali perusahaan sektor keuangan. Metode yang digunakan dalam penelitian ini ialah metode deskriptif menggunakan pendekatan kuantitatif. Analisis data yang digunakan ialah analisis crosstab. Aspek kualitas laporan keuangan dalam penelitian dianalisis dari aspek manajemen laba (penghindaran kerugian, penghindaran penurunan laba, akrual) serta kualitas audit (opini audit, ukuran KAP, sertafee audit). Aspek-aspek tersebut kemudian dirangkum dalam Financial Reporting Quality Index (FRQI). Penelitian ini menilai kualitas laporan keuangan secara komprehensif menggunakan indeks terbaru yang sudah mengakomodasi berbagai elemen pelaporan keuangan. Berdasarkan masing-masing kategori laporan keuangan yang paling tinggi diduduki oleh kelompok perusahaan berukuran sangat kecil, kelompok peusahaan berumur menengah dan kelompok industri manufaktur.Sedangkan laporan keuangan yang paling rendah dari masing-masing kategori diduduki oleh kelompok perusahaan berukuran kecil, kelompok perusahaan berumur tua dan kelompok industri sektor utama. Penelitian ini dapat digunakan sebagai acuan bagi pembaca/pengguna laporan keuangan dan investor ketika akan melakukan keputusan ekonomis.
\end{abstract}

Kata kunci : kualitas laporan keuangan, manajemen laba, kualitas audit

\begin{abstract}
The purpose of this research is to identify the financial reporting quality in Indonesia. In this research, the financial reporting quality is analyzed based on scales of companies and their industries. The research focuses on companies which are registered in Indonesia Stock Exchange, excludes companies which engage in financial sectors. The research focused on companies listed on the Indonesia Stock Exchange totaling 599 companies except financial sector companies. This research was used the descriptive method by a quantitative approach. The populations were 599 companies. Purposive sampling technique was conducted to get the samples where the companies must have the criteria needed in this research. Secondary data was used to present information which was served in a financial report. Data analyzing used crosstab analysis. The quality aspects of the financial report are profit management aspect (loss
\end{abstract}


and decreasing profit avoidances, accruals) and audit quality (audit opinion, KAP scale, and audit fee). Then those aspects are concluded in Financial Reporting Quality Index (FRQI). This study assesses the quality of financial statements comprehensively using the latest indexes that have accommodated various elements of financial reporting. Based on each category the highest financial statements are occupied by very small group of companies, middle-aged groups of companies and manufacturing industry groups. While the lowest financial statements of each category are occupied by small-sized group companies, the old group of companies and main sector industry group. This research can be used as a reference for readers / users of financial statements and investors when making economic decisions.

Keywords: financial report quality, earnings management, audit quality

\section{PENDAHULUAN}

Kinerja perusahaan dapat diukur dan dinilai melalui laporan keuangan.Dengan mengemban peran penting bagi perusahaan, laporan keuangan yang berkualitas seharusnya diungkapkan sesuai fakta serta terhindar dari rekayasa(Wicaksono \& Yuyetta, 2013).Dengan karateristik kualitatif yaitu andal, relevan, dapat dipahami dan dapat dibandingkan(PSAK No.1 Revisi, 2009).Apabila laporan keuangan tidak mencakup karakteristik tersebut maka kurang bermanfaat bagi pemakai laporan keuangan yang tidak memiliki pengetahuan akuntansi(Rusmanto, 2008).Tujuan menyusun laporan keuangan menurut IAI (2011)ialah memberikan informasi sebenarnya mengenai kinerja perusahaan, posisi keuangan serta perubahannya yang berguna bagi pemakai laporan keuangan sebagai alat untuk mengambil keputusan.Keputusan yang diambil oleh pemakai laporan keuangan berdasarkan analisis terhadap informasi yang disajikan oleh laporan keuangan.

Fokus utama informasi laporan keuangan yang sering menjadi pertimbangan dalam pengambilan keputusan yaitu kemampuan perusahaan menghasilkan laba (Mulyadi, 2002).Laba historismembantu memprediksi keadaan perusahaan, mengatur efisiensi manajemen, pendistribusian dividen mendatang dan acuan bagi pengambilan keputusan ekonomis dimasa depan(Hendriksen, 2000).Kecenderungan para pemakai laporan keuangan yang selalu mengacu terhadap labamemungkinkan manajemen melakukan tindak kecurangan dengan cara manipulasi laba atau manajemen laba dengan tujuan menghasilkan laba yang dianggap normal bagi perusahaan(Bartov, 1993).Healy dan Wahlen(1999)mengungkapkan manajemen laba terjadi saat manajemen memakai pendapatnya atas laporan keuangan dan penyusunan transaksi guna untuk mengubah informasi laporan keuangan menjadi menyesatkan bagi pemakai laporan keuangan.Kegiatan menurunkan maupun menaikkan laba lewat manajemen laba baik dengan cara yang tidak sesuai atau sesuai dengan asas akuntansi yang berlaku disebut dengan agresivitas pelaporan keuangan(Frank, Lynch, \& Sonja, 2009).

Agresitivitas laporan keuangan dan manajemen labamembuat potensi misalokasi sumber daya(Kamila, 2014)yang menyebabkan persepsi salah bagi pemakai laporan keuangan mengenai kinerja perusahaan.Indriani, Darmawan dan Nurhawa (2014)menyatakan bahwa laporan keuangan sebagai dasar bagi pemakai (investor, kreditur) untuk menilai kinerja perusahaan.Dalam laporan keuangan mengandung informasi laba bersih perusahaan yang digunakan sebagai pertimbangan bagi investor untuk mengambil keputusan ekonomis.Apabila laporan keuangan yang dihasilkan menunjukkan adanya manajemen laba maka laporan keuangan tidak memenuhi syarat reliable dimana mengandung kesalahan material, menyesatkan, dan tidak 
dapat diandalkan karena penyajian tidak jujur(Ikatan Akuntansi Indonesia, 2011).Kondisi ini dapat menjadikan kualitas laporan keuangan menurun.Jika kualitas laporan keuangan menurun, maka tingkatdaya saing efisiensi investasi secara internasional menurun, dan sebaliknya(Chen, Hope, Li, \& Wang, 2011)dan(Biddle, Hilary, \& Verdi, 2009).Artinya, kualitas laporan keuangan yang semakin rendahakanmenaikkan asimetri informasi yang digunakan untuk membuat keputusan. Oleh karena itu, perlu dilakukan evaluasi terhadap kualitas laporan keuangan yang ada di Indonesia.

Penelitian terdahulu telah menilai kualitas pelaporan keuangan secara parsial dari aspek relevansi, konservatisme, dan ketepatan waktu(Fanani (2009); Setiany dan Wulandari (2015); dan Setyawati (2015).Penelitian sebelumnya menganalisis pengaruh kualitas pelaporan keuangan dengan berbagai variabel.Sedangkan penelitian kali ini menilai kualitas pelaporan keuangan secara lebih komprehensif dengan mengunakan indeks kualitas yang mengacu penelitianTang, Chen dan Lin(2016)yang sudah mengakomodasi berbagai elemen pelaporan keuangan seperti rasio penghindaran kerugian, rasio penurunan laba, rasio akrual, rasio opini audit yang berkualitas, Non-big four auditor ratio, dan audit-fee ratio.Penelitian kali ini tidak menganalisis pengaruh namun hanya ingin mendeskripsikan bagaimana kualitas laporan keuangan yang ada di Indonesia melihat dan membandingkan jenis perusahaan, ukuran dan umur perusahaan di Indonesia. Tujuan dari penelitian ini yaitu untuk melihat bagaimana kualitas laporan keuangan di Indonesia.Penelitianberfokus pada perusahaan yang terdaftar di Bursa Efek Indonesia kecuali perusahaan sektor keuangan, dikarenakan pada sektor tersebut strukur laporan keuangan tidak memenuhi indikator yang ada dalam penelitian ini. Manfaat penelitian ini bagi pemakai laporan keuangan diharapkan dapat berguna sebagai referensi untuk menilai kualitas laporan keuangan dengan indikator-indikator yang dipakai dalam penelitian ini.

\section{Kualitas Laporan Keuangan}

\section{KAJIAN PUSTAKA}

Laporan keuangan yang berkualitas harus mampu mencerminkan seberapa jauh laporan keuangan menghasilkan informasi yang jujur dan adil tentang penyajian posisi keuangan yang jadi dasar kinerja perusahaan (FASB, IASB, ASB dan AASB).Kualitas laporan keuangan ialah laporan keuangan yang mampu merepresentasikan karakteristik kualitatif seperti yang telah ditentukan oleh IAI dalam kerangka dasar laporan keuangan (2009).

Adapun karaktersitik yaitu: Pertama yaitu Andal, ketika laporan keuanngan disajikan secara jujur, terbebas dari kesalahan material dan infomasi menyesatkan bagi pemakai laporan keuangan sebagai pertimbangan pengambilan keputusan. Kedua, yaitu relevan, ketika laporan keuangan dapat digunakan untuk mengevaluasi, mengoreksi dan mengegaskan hasil peristiwa yang sedang maupun telah terjadi. Ketiga, ialah dapat dibandingkan, yaitu ketika pemakai dapat mengidentifikasi, memprediksi trend (kecenderungan) kinerja dan posisi keuangan perusahaan baik antar periode maupun antar perusahaan yang sejenis melalui laporan keuangan. Karakteristik yang keempat (dapat dipahami) akan terpenuhi apabila informasi yang tercantum mudah dipahami dan dibaca oleh pemakai laporan keuangan yang dalam hal ini telah memiliki pengetahuan memadai.

\section{Manajemen Laba}

Tolak ukur yang digunakan oleh pemegang saham untuk menilai kinerja dan posisi keuangan suatu perusahaan ialah basis penghasilan dan laba (Tang, Chen, \& Lin, 2016). Perusahaan yang memiliki kenaikan laba secara terus menerus, sahamnya akan bernilai premium dan sebaliknya Barth (1999a, 1999b). Jika laba tidak dapat dicapai oleh perusahaan pada 
waktunya, harga saham akan dikenakan pinalti (Tang, Chen, \& Lin, 2016), hal ini memotivasi manajemen untuk menyajikan laba yang lebih menguntungkan dengan manajemen laba (Healy \& Wahlen, 1999) sehingga membuat laba terus meningkat secara halus meskipun terjadi kerugian. Schipper (1989) mengemukakan bahwa manajemen laba merupakan campur tangan manajemen dengan suatu maksud yang dilakukan secara sengaja. Perilaku menghindari kerugian dan tidak melaporkan penurunan laba akan mengaburkan hubungan antara laba akuntansi yang merepresentasikan kinerja ekonomi, akibatnya akan mengurangi kualitas laporan keuangan (Tang, Chen, \& Lin, 2016).

\section{Akrual}

Dasar akrual merupakan pengakuan transaksi ketika kejadian bukan ketika penerimaan atau pembayaran kas dan setara kas.Pencatatan dilakukan dalam catatan akuntansi kemudian dilaporkan dalam laporan keuangan pada periode yang bersangkutan (IAI, 2009).Besaran akrual mencerminkan tingkat kebijakan agresivitas dan konservatisme laporan keuangan (Tang, Chen, \& Lin, 2016).Konservatisme menandakan penggabungan kerugian ekonomi kedalam laba akuntansi dari pada kedalam keuntungan ekonomis, yang muncul untuk mengurangi informasi asimetri antara manajemen dan investor.

Tinggi rendahnya akrual digunakan untuk mengukur perilaku agresif laporan keuangan (Tang, Chen, \& Lin, 2016).Dengan asumsi arus kas operasi bernilai konstan, maka timbulnya akrual akan mengindikasikan adanya peningkatan agretivitas pelaporan laba yang berkaitan dengan kualitas laporan keuangan.

\section{Opini Auditor Eksternal}

Opini audit merupakan laporan yang diberikan oleh seorang akuntan publik sebagai hasil penilaian kewajaran laporan keuangan yang disajikan oleh klien (Ardiyos, 2007). Kamus Istilah Akuntansi (2004)menyatakan bahwa opini audit ialah laporan yang berasal dari auditor yang menyatakan pemeriksaan kewajaran laporan keuangan telah dilaksanakan sesuai dengan aturan pemeriksaan akuntan disertai dengan pendapat auditor. Opini audit menjadi terjemahan dari laporan keuangan yang digunakan oleh pemakai laporan keuangan dalam pengambilan keputusan yang berisi pernyataan profesional sebagai kesimpulan pemeriksaan kewajaran laporan keuangan perusahaan.

Hasil opini auditor yang berkualitas ialah ketika probabilitas auditor independent melaporkan laporan audit dengan opini yang sesuai dengan keadaan (Watkins, Hilson, \& Morecroft, 2005).Menurut PSA 29 Seksi 505 dalam Standart Profesional Akuntan Publik (2001)lima pendapat auditor ialah: Pertama, pendapat wajar tanpa pengecualian ialah ketika auditor menyatakan bahwa laporan keuangan disajikan secara wajar dalam segala hal yang material; Kedua, pendapat wajar tanpa pengecualian dengan bahasa penjelasan ialah auditor memberikan paragraf penjelas tambahan karena ada keraguan atas konsep going concern dan kekonsistenan dalam penerapan GAAP; Ketiga, pendapat wajar dengan pengecualian ialah auditor mengungkapkan bahwa laporan keuangan telah disajikan dengan wajar dalam segala hal yang material kecuali untuk item tertentu yang menjadi pengecualian; Keempat, pendapat tidak wajar ialah auditor menyatakan bahwa laporan keuangan tidak disajikan secara wajar, tidak terbebas dari salah saji material; dan yang terakhir ialah pendapat tidak memberikan pendapat, ketika auditor tidak puas akan semua penyajian laporan keuangan.

Auditor yang memberikan opini audit wajar tanpa pengecualian menandakan bahwa laporan keuangan berkualitas dikarenakan laporan keuangan telah disajikan secara wajar dan terhindar dari segala macam kesalahan material. Sehingga laporan keuangan akan memenuhi karakteristik andal dan reliable. 


\section{Ukuran Kantor Akuntan Publik (KAP)}

Ukuran KAP menentukan perbedaan kualitas audit yang dihasilkan telah dibuktikan secara empiris. Nariman (2015)mengatakan ukuran KAP dibedakan menjadi KAP besar (Bigfour accounting firms) dan KAP kecil (Non-Big Four accounting firms).Perbedaan utama dari KAP tersebut terdapat pada total anggota, total klien, dan total pendapatan yang diterima dalam satu periode.Auditor Big Four umumnya dianggap independen, karena memiliki pengalaman, dan keahlian yang lebih baik dari pada auditor Non-Big Four (Carcello \& Nagy, 2003).Auditor Big Four juga memiliki investasi yang lebih besar pada pelatihan professional dan pendidikan (Dopuch, Holthausen, \& Leftwich, 1986).Tang, et al. (2016)mengemukakan bahwa proporsi audit antar perusahaan dapat dibandingkan dengan mempertimbangkan karakteristik laporan keuangan yang diterbitkan oleh auditor.

Auditor yang memiliki kualitas rendah akan menerbitkan pendapat wajar tanpa pengecualian tanpa melakukan pengujian substantif ketat (Tang, Chen, \& Lin, 2016). Tingkat kualitas auditor akan terkait dengan kualitas laporan keuangan, karena dimensi penting kualitas laporan keuangan adalah kualitas auditor. Dengan demikian, auditor yang memiliki kualitas tinggi mempengaruhi kualitas laporan keuangan dengan cara memicu klien untuk mengungkapkan keuntungan dan kerugian tepat pada waktunya dan membatasi agresitivitas laporan keuangan.

\section{Fee Auditor}

Fee merupakan sumber penghasilan akuntan publik sekaligus menjadi masalah yang dilematik (Herawaty, 2011).Fee auditor diperoleh dari klien yang diaudit.Auditor diharuskan bertindak independen dalam memberikan opini. Namun, disisi lain auditor juga mendapat imbalan (fee) atas jasa yang sudah diberikan. Menurut Mulyadi (2009)Fee audit ialah penghasilanyang diterima oleh akuntan publik setelah melaksanakan jasa audit dengan besaran yang tergantung dari kompleksitas jasa, risiko penugasan, struktur biaya KAP, dan tingkat keahlian auditor.

Pertimbangan ketetapan fee audit oleh akuntan publik berdasarkan keputusan ketua umum institut akuntan publik Indonesia No: kep.024/IAPI/VII/2008 sebagai berikut : (1) Kebutuhan klien; (2) Tugas dan tanggung jawab menurut hukum; (3) Independensi; (4) Tingkat keahlian dan tanggung jawab, serta tingkat kompleksitas pekerjaan (5) Banyaknya waktu yang diperlukan secara efektif digunakan oleh akuntan publik dan stafnya untuk menyelesaikan pekerjaan; dan (6) Basis penetapan fee yang disepakati.

Artinya, Fee audit merupakan salah satu indikator penting terkait dengan pemeriksaan laporan keuangan. Fee audit yang semakin tinggi akan menghasilkan kualitas audit yang tinggi, karena semakin luas prosedur audit sehingga hasil audit akan akurat dan dipercaya (Chrisdinawidanty, Tugiman, \& Mushlih, 2016). Auditor dapat lebih mendalam dan luas dalam melakukan pendeteksian kejanggalan. Kejanggalan yang terdeteksi menggambarkan kualitas proses audit yang tinggi dengan penerapan standar audit dan akuntansi (Agoes, 2012, p. 56). Biaya audit dalam satu periode dan estimasi biaya operasional yang dibutuhkan untuk melalukan proses audit sebagai peningkatan kualitas audit (Kurniasih dan Rohman, 2014).

\section{Jenis Penelitian}

\section{METODE PENELITIAN}

Penelitian ini merupakan penelitian deskriptif kuantitatif, yang merupakan salah satu jenis dari penelitian kuantitatif yang bertujuan untuk mengungkapkan fenomena dengan angkaangka. 


\section{Sampel dan data}

Penelitian ini menggunakan populasi seluruh perusahaan pada tahun 2017 yang terdaftar di BEI (Bursa Efek Indonesia) yang berjumlah 599 perusahaan.Sampel diambil menggunakan teknik purposive sampling dengan kriteria perusahaan memiliki data yang dibutuhkan dipenelitian ini. Data sekunder laporan keuangantahun 2017 diakses melalui database di www.idx.co.id Perusahaan-perusahaan dikelompokkan berdasarkan jenis sektor, ukuran, dan usianya.

\section{Definisi Operasional dan Pengukuran Variabel}

Kualitas laporan keuangan menurut IAI dalam KDPPLK (2009) ialah laporan keuangan yang mampu merepresentasikan karakteristik kuanlitatif. Tang, et.al (2016) menyatakan bahwa kualitas laporan keuangan dapat diukur menggunakan indikator berikut ini:

- Rasio penghindaran kerugian/Loss Avoidance Ratio (LAR)

Indikator pertama yang akan digunakan untuk mengukur manajemen laba. Rasio penghindaran kerugian diperhitungkan denganjumlah perusahaan dengan laba kecil dibagi dengan jumlah perusahaan dengan kerugian kecil.Konsisten dengan penelitan sebelumya (Tang, Chen, \& Lin, 2016)jika semakin tinggi rasio, maka menandakan semakin tinggi pula manajemen laba dalam kelompok perusahaan yang dianalisis. Sehingga akan semakin rendah kualitas laporan keuangan.

$$
\mathrm{LAR}=\frac{\text { Jumlah perusahaan dengan laba kecil }}{\text { Jumlah perusahaan dengan rugi kecil }}
$$

Besar kecilnya laba/rugi perusahaan dihitung berdasarkan nilai rasio laba bersih terhadap total asset, sebagai berikut:
a. Laba kecil
: hasil diantara $0-0,01$
b. Rugi kecil
: hasil Diantara $-0,01-0$
c. Tidak masuk kategori
: hasil diluar dari keduanya.

- Rasio penghilangan penurunan laba/Profit decline avoidance ratio (PDAR)

Indikator kedua untuk mengukur manajemen laba ialah PDAR. Rasio penurunan laba dihitung dengan cara membagi total peningkatan laba kecil dengan total penurunan laba kecil. Konsiten dengan penelitian terdahulu (Tang, Chen, \& Lin, 2016)semakin tinggi rasio menunjukkan tingginya manajemen laba dalam kelompok perusahaan yang dianalisis.

$$
P D A R=\frac{\text { Jumlah perusahaan dengan kenaikan laba kecil }}{\text { Jumlah perusahaan dengan penurunan laba kecil }}
$$

Besar kecilnya kenaikan/penurunan laba perusahaan dihitung berdasarkan nilai rasio perubahan laba bersih terhadap total asset tahun sebelumnya, sebagai berikut:
a. Laba kecil
: hasil diantara $0-0,005$
b. Rugi kecil
: hasil Diantara -0,005 - 0
c. Tidak masuk kategori
: hasil diluar dari keduanya.

- Rasio akrual/Accruals ratio (AR)

Rasio akrual merupakan indikator yang digunakan untuk menghitung besaran agresivitas atau konservatisme dalam laporan keuangan.Konsisten dengan penelitian 
sebelumya (Tang, Chen, \& Lin, 2016), semakin kecil rasio akrual maka semakin berkurang manajemen laba. Untuk menghitung rasio akrual yaitu rumusdibawah ini:

$$
A R=\frac{(\triangle C A-\Delta C a s h)-(\Delta C L-\triangle S T D E B T-\Delta T P)-D e \rho}{T A}
$$

Keterangan :

$$
\begin{array}{ll}
\triangle C A & =\text { perubahan pada aset lancar } \\
\triangle C \text { ash } & =\text { perubahan pada kas } \\
\triangle C L & =\text { perubahan pada kewajiban lancar } \\
\triangle S T D E B T & =\text { perubahan hutang dagang } \\
\triangle T P & =\text { perubahan pajak penghasilan terhutang } \\
\text { Dep } & =\text { beban depresiasi asset } \\
\text { TA } & =\text { total asset tahun sebelumnya }
\end{array}
$$

Rasio akrual masing masing kelompok perusahaan, mengacu pada nilai median AR perusahaan pada kelompok yang dianalisis.

- Rasio kualitas opini audit/Qualified audit opinion ratio (QAOR)

Variabel selanjutnya mempertimbangkan variable audit. Rasio kualitas opini auditor dihitung dengan cara membagi total angka dari kualitas opini audit dengan total angka dari auditor.

$$
Q A O R=\frac{\text { Jumlah opini auditor selain wajar tanpa pengcualian }}{\text { Jumlah perusahaan }}
$$

- Rasio auditor Non-Big four/Non-big four ratio (NBAR)

Rasio terahir yang digunakan untuk menilai kualitas keuangan yaitu NBAR. Konsisten dengan penelitian yang sebelumnya (Tang, Chen, \& Lin, 2016)cara menghitung NBAR yaitu 1 - rasio auditor big four.

$$
N B A R=1-\frac{\text { Total perusahaan yang diaudit oleh auditor big four }}{\text { Total perusahaan }}
$$

- $\quad$ Rasio fee audit/Audit fee Ratio (AFR)

Indikator yang selanjutnya untuk menentukan kualitas keuangan ialah rasio fee audit. Konsiten dengan peneltian sebelumya (Tang, Chen, \& Lin, 2016) dengan menggunakan fee atas jasa yang diberikan auditor untuk membedakan kualitas audit. Rasio fee audit dihitung berdasarkan median dari membagi total fee audit dengan total asset.Proxy dari auditor fee adalah jasa professional (Hanif \& Putri, 2014) dan (Kovinna $\&$ Betri, 2010).

AFR $=\frac{\text { Feeaudit }}{\text { TotalAset }}$

- Indeks kualitas laporan keuangan/Financial reporting quality index (FRQI)

Tang, et.al (2016) menyatakan indeks kualitas laporan keuangan dihitung berdasarkan keenam indikator akuntansi dan audit, yaitu: 
Tabel1.Indeks Kualitas Laporan Keuangan

\begin{tabular}{|c|c|c|}
\hline Variabel & Nama Variabel & Pengukuran \\
\hline LAR & Loss Avoidance Ratio & Kelompok perusahaan dengan nilai terendah akan diberikan \\
\hline PDAR & $\begin{array}{l}\text { Profit Decline Avoidance } \\
\text { Ratio }\end{array}$ & $\begin{array}{l}\text { skor } 100 \text {. Sebaliknya, kelompok perusahaan dengan nilai } \\
\text { tertinggi akan diberi skor } 0 \text { dan kelompok perusahaan yang }\end{array}$ \\
\hline QOAR & $\begin{array}{l}\text { Qualified Audit Opinion } \\
\text { Ratio }\end{array}$ & \\
\hline NBAR & $\begin{array}{l}\text { Non-Big Four Auditor } \\
\text { Ratio }\end{array}$ & \\
\hline AR & Accruaks Ratio & $\begin{array}{l}\text { Kelompok perusahaan dengan nilai terendah akan diberikan } \\
\text { skor 100. Sebaliknya, kelompok perusahaan dengan nilai } \\
\text { tertinggi akan diberi skor } 0 \text { dan kelompok perusahaan yang } \\
\text { memiliki nilai lain menyesuaikan secara proporsional. Namun, } \\
\text { khusus untuk AR apabila positif maka akan langsung diberi } \\
\text { skor } 0\end{array}$ \\
\hline AFR & Audit Fee Ratio & $\begin{array}{l}\text { Berbanding terbalik dengan kelima indikator. Kelompok } \\
\text { perusahaan dengan nilai tertinggi akan diberikan skor } 100 \text {. } \\
\text { Sebaliknya, kelompok perusahaan dengan nilai terendah akan } \\
\text { diberi skor } 0 \text { dan kelompok perusahaan yang memiliki nilai } \\
\text { lain menyesuaikan secara proporsional. }\end{array}$ \\
\hline FRQI & $\begin{array}{l}\text { Financial Reporting } \\
\text { Quality Index }\end{array}$ & $\begin{array}{l}\text { Rata-rata skor LAR, PDAR, AR, QDAR, dan NBAR pada } \\
\text { setiap kelompok perusahaan. }\end{array}$ \\
\hline
\end{tabular}

Sumber data : Penelitian Qingliang Tang, Huifa Chen, Zhijun Lin (2016)

\section{Tahapan Analisis}

Penelitian ini merupakan penelitian deskriptif kuantitatif yang menggunakan crosstab, untuk mentabulasikan atau menjelaskan kualitas laporan keuangan antar kelompok perusahaan yang diukur dengan indeks kualitas laporan keuangan/Financial reporting quality index (FRQI) di tiap-tiap kelompok, ukuran dan umur perusahaan. Tahapan yang pertama, dilakukan yaitu perhitungan dan identifikasi kategori penghindaran kerugian, penghilangan penurunan laba, akrual, kualitas opini audit, audit Big four dan fee audit pada tiap perusahaan. Kedua, pengelompokan perusahaan berdasarkan ukuran sektor industri dan umur.Ketiga, perhitungan LAR, PDAR, AR, QAOR, NBAR dan AFR dalam tiap tiap ukuran perusahaan dan sektor.Keempat, ialah perhitungan FRQI pada tiap-tiap ukuran perusahaan dan sektor, dan yang terakhir, yaitu analisis tabulasi (crosstab) kualitas laporan keuangan tiap-tiap kelompok, ukuran dan umur peusahaan.

\section{Hasil Pengumpulan Data}

\section{HASIL DAN PEMBAHASAN}

Penelitian ini bertujuan untuk mengetahui bagaimana kualitas laporan keuangan perusahaan publik di Indonesia yang terdaftar pada BEI pada tahun 2017. Berdasarkan kriteria sampel yang telah ditentukan, diperoleh sampel penelitian sebesar 388 perusahaan dari 599 perusahaan yang mejadi populasi penelitian. Analisis ukuran dan usia berdasarkan perankingan jumlah perusahaan dibagi lima. Jumlah sampel dari kategori Industri sektor utama berjumlah 60 perusahaan, manufaktur berjumlah 111 perusahaan dan jasa berumlah 217 perusahaan. Jumlah sampel dari kategori ukuran perusahaan masing-masing berjumlah 77 perusahaan. Kategori yang terakhir yaitu kategori usia perusahaan, untuk usia sangat muda dengan range tahun 2001-2015 berjumlah 83 perusahaan, usia muda dengan range tahun 1993-2000 berjumlah 78 perusahaan, usia menengah dengan range tahun 1985 - 1992 berjumlah 76, usia tua dengan range tahun 1977 
- 1984 berjumlah 71 perusahaan, dan usia sangat tua dengan range tahun $1872-1976$ berjumlah 80 perusahaan.

\section{Statistik Deskriptif}

Statistik diskriptif bertujuan untuk melihat persebaran data dari setiap variabel penelitian ini.Dibawah ini merupakan hasil dari statistik deskriptif dari setiap variabel penelitian.

Tabel2.Statistik Deskriptif

\begin{tabular}{|c|c|c|c|}
\hline Minimum & Rata-rata & Maksimum & St Dev \\
\hline 16.823 .208 .531 & 9.147 .788 .265 .297 & 295.646.000.000.000 & 22.969 .881 .367 .846 \\
\hline Akrual & $-0,18$ & 27,69 & 4,19 \\
\hline Audit Fee & 0,17 & 56,15 & 2,86 \\
\hline Kategori & \multicolumn{3}{|c|}{ Jumlah Perusahaan } \\
\hline Ukuran KAP & & \multicolumn{2}{|c|}{388} \\
\hline Big Four & & \multicolumn{2}{|r|}{166} \\
\hline Non-Big Four & & \multicolumn{2}{|r|}{222} \\
\hline Opini Auditor & & \multicolumn{2}{|r|}{388} \\
\hline Wajar Tanpa Pengecualian & & \multicolumn{2}{|r|}{380} \\
\hline Wajar Dengan Pengecualian & & \multicolumn{2}{|r|}{6} \\
\hline Tidak Wajar & & \multicolumn{2}{|r|}{0} \\
\hline Tidak Menyatakan Pendapat & & \multicolumn{2}{|r|}{2} \\
\hline Laba (Rugi) Kecil & & \multicolumn{2}{|r|}{388} \\
\hline Laba Kecil & & \multicolumn{2}{|r|}{38} \\
\hline Rugi Kecil & & \multicolumn{2}{|r|}{14} \\
\hline Tidak Termasuk Kategori & & \multicolumn{2}{|r|}{342} \\
\hline Kenaikan (Penurunan) Laba & & \multicolumn{2}{|r|}{388} \\
\hline Kenaikan Laba Kecil & & \multicolumn{2}{|r|}{32} \\
\hline Penurunan Laba Kecil & & \multirow{2}{*}{\multicolumn{2}{|c|}{$\begin{array}{c}19 \\
331\end{array}$}} \\
\hline Tidak Termasuk Kategori & & & \\
\hline
\end{tabular}

Sumber : data penelitian (2018)

Total aset digunakan untuk mengkategorikan ukuran perusahaan. Total aset minimum dari seluruh perusahaan di Indonesia sebesar Rp. 16.823.208.531, yang menandakan perusahaan tersebut merupakan perusahaan yang paling kecil. Sedangkan, total aset maksimum dari seluruh perusahaan di Indonesia sebesar Rp. 295.646.000.000.000, yang menandakan perusahaan tersebut paling besar atau bisa dikatakan perusahaan raksasa. Rata-rata dari total aset seluruh perusahaan di Indonesia sebesar Rp. 9.147.788.265.297 yang menandakan perusahaan di Indonesia memiliki ukuran yang sangat bervariasi dari yang sangat kecil sampai dengan perusahaan raksasa dengan standart deviasi sebesar Rp. 22.969.881.367.846.

Akrual digunakan untuk mengitung besaran agresivitas atau konservatisme dalam pelaporan keuangan.Rata-rata akrual perusahaan di Indonesia sebesar -0,18. Akrual tertinggi sebesar 27,69 dan akrual terendah sebesar -48,86 dengan standart deviasi sebesar 4,19. Hal ini menandakan bahwa pelaporan agresif dilakukan oleh beberapa perusahaan di Indonesia.

Audit fee yang dibayarkan kepada auditor juga sangat bervariasi. Hal ini dilihat dari ratarata audit fee sebesar 0,17. Dari rata-rata tersebut, maksimum audit fee sebesar 56,16 dan minimum audit fee 0,00 dengan standart deviasi sebesar 4,19.

Sebagian besar perusahaan yang ada di Indonesia yaitu sejumlah 222 perusahaan, diaudit oleh KAP Non-Big Four ini menandakan sebagian besar kualitas audit belum diyakini dengan baik, karena perusahaan yang di audit oleh KAP Non-Big Four lebih banyak dari pada perusahaan yang diaudit oleh KAP Big-Four sebesar 166 perusahaan.Namun, sebagian besar 
atau hampir keseluruhan perusahaan sejumlah 380 sudah memiliki opini wajar tanpa pengecualian.Hanya 6 perusahaan yang memiliki pendapat wajar dengan pengecualian, 2 perusahaan yang auditor menolak memberikan pendapat dan tidak ada satupun perusahaan yang memiliki pendapat tidak wajar.Hal ini bisa dikatakan bahwa sebagian besar laporan keuangan sudah mengikuti GAAP, terbebas dari salah saji material dan disajikan secara wajar.

Sebagian besar perusahaan di indonesia sudah tidak melakukan praktik manajemen laba melalui penghindaran kerugian ataupun penghilangan penurunan laba. Perusahaan yang memiliki laba kecil sejumlah 38 perusahaan dan yang memiliki rugi kecil sebesar 14, untuk sisanya sejumlah 342 tidak memiliki laba/rugi kecil. Selain itu, perusahaan yang mengalami kenaikan laba kecil sejumlah 32 perusahaan dan yang memiliki penurunan laba kecil hanya 19 perusahaan, untuk sisanya sejumlah 331 perusahaan tidal memiliki penurunan laba/rugi kecil.

\section{PEMBAHASAN}

Kualitas laporan keuangan dinilai berdasarkan tinggi rendahnya FRQI (Financial Reporting Quality Index). Semakin tinggi FRQI maka akan semakin tinggi kualitas laporan keuangan dan sebaliknya(Tang, Chen, \& Lin, 2016). Kualitas laporan keuangan juga dinilai berdasarkan tingkat manajemen laba yang dilakukan oleh kelompok perusahaan. Jika manajemen laba yang dilakukan oleh kelompok perusahaan sangat tinggi, maka akan menaikkan asimetri informasi yang digunakan untuk membuat keputusan.Indikator untuk menghitung manajemen laba yaitu tinggi rendahnya tindak penghindaran kerugian (LAR), penghilangan penurunan laba (PDAR) dan tinggi rendahnya akrual yang sebagai penilaian agresivitas laporan keuangan. Semakin tinggi skor LAR, PDAR dan AR maka semakin tinggi pula indikasi adanya manajemen laba.

Hal lain yang mempengaruhi kualitas laporan keuangan yaitu opini auditor (QAOR), ukuran KAP yang mengaudit (NBAR) dan jumlah fee yang dibayarkan kepada auditor (AFR). Berbanding terbalik dengan indikator manajemen laba, indikator audit ini dinilai ketika semakin tinggi skor dari QAOR, NBAR, dan AFR maka kualitas laporan keuangan semakin naik pula.Dengan demikian laporan keuangan yang berkualitas merupakan laporan keuangan yang terbebas dari manajemen laba dan memiliki kualitas audit yang baik.

\section{Kualitas Laporan Keuangan Berdasarkan Ukuran Perusahaan}

Hasil perhitungan rasio-rasio dan FRQI yang telah dilakukan berdasarkan kategori ukuran perusahaan, peringkat pertama diduduki oleh kelompok perusahaan berukuran sangat kecil dengan skor FRQI sebesar 65.Disusul oleh kelompok perusahaan berukuran besar sebagai peringkat kedua dengan skor FRQI sebesar 56. Selisih tipis satu poin dengan kelompok perusahaan berukuran besar,peringkat ketiga diduduki oleh kelompok perusahaan berukuran menengah dengan skor FRQI sebesar 55.Selanjutnya, peringkat keempat diduduki oleh kelompok perusahaan berukuran sangat besar dengan skor FRQI sebesar 49. Terakhir, peringkat kelima diduduki oleh kelompok perusahaan berukuran kecil dengan skor FRQI sebesar 42. Hasil perhitungan disajikan dalam Tabel 4 dibawah ini: 
Tabel 3. Indeks Kualitas Laporan Keuangan Berdasarkan Ukuran Perusahaan

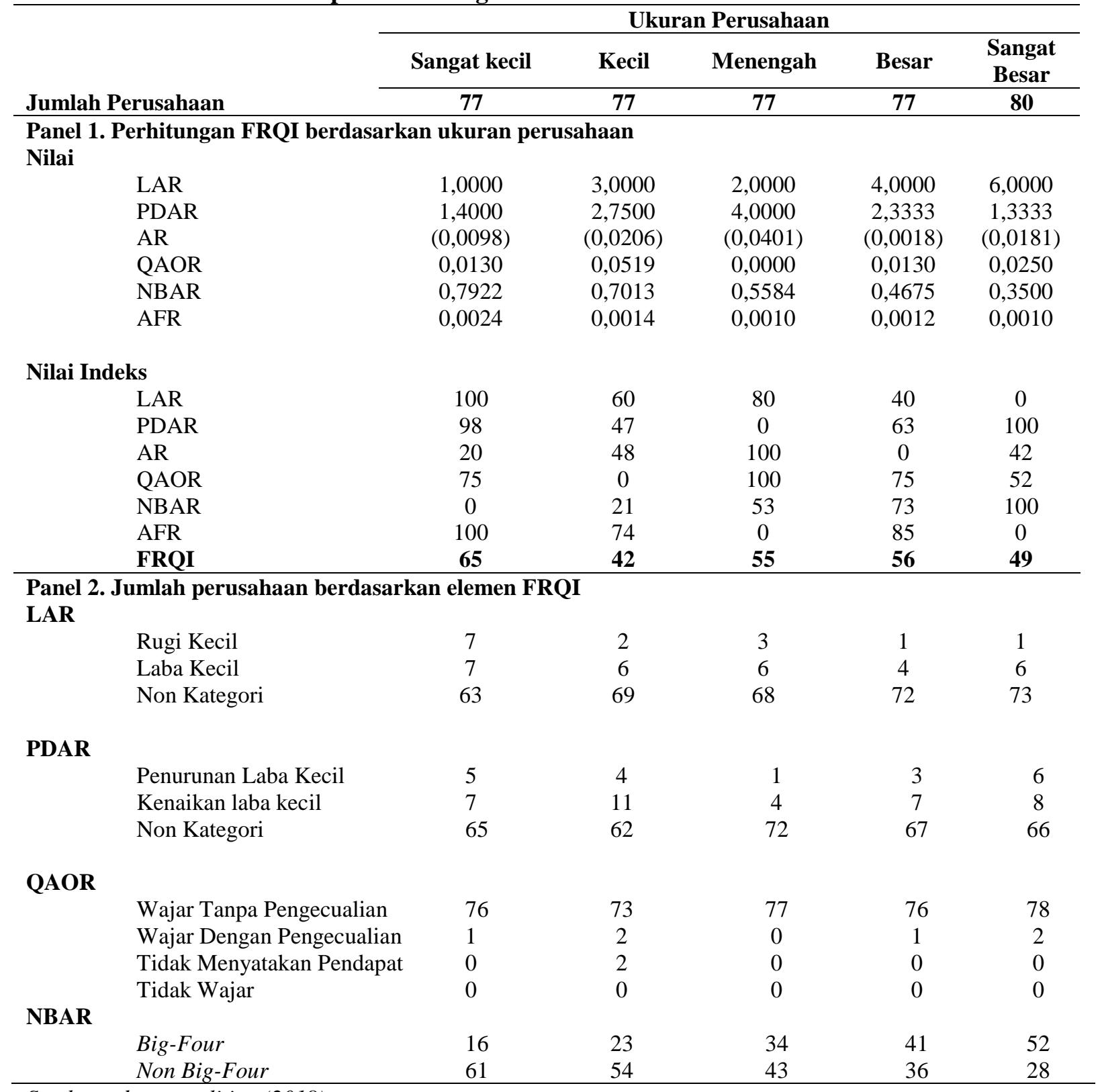

Sumber : data penelitian (2018)

Berdasarkan hasil perhitungan Tabel 4 diatas, peringkat pertama dari penilaian kualitas laporan keuangan kategori ukuran perusahaan diduduki oleh kelompok perusahaan berukuran sangat kecil. Dibuktikan dengan skor FRQI (Financal Reporting Quality Index) bernilai paling tinggi, yaitu sebesar 65.Hal ini terjadi karena, dalam kelompok perusahaan sangat kecil indikasi adanya manajemen laba rendah.

Indikasi rendah atau tingginya manajemen laba tercermin dari perhitungan skor LAR yang memiliki skortertinggi yaitu 100.Artinya,rendahnya tindak penghindaran kerugian yang dilakukan oleh kelompok perusahaan berukuran sangat kecil sebagai salah satu indikasi manajemen laba.Selain rendahnya penghindaran kerugian, skor PDAR yang cukup tinggi sebesar 
98, mengindikasikan bahwa penghilangan penurunan laba yang juga rendah.Apabila tingkat manajemen laba semakin rendah, maka akan diikuti dengan meningkatnya kualitas laporan keuangan yang mengakibatkan daya saing efisiensi investasi secara internasional naik pula (Chen, Hope, Li, \& Wang, 2011) dan (Biddle, Hilary, \& Verdi, 2009).

Kelompok perusahaan berukuran sangat kecil sangat jarang di audit oleh KAP Big-Four (skor NBAR sebesar 0).Namun,kelompok perusahaan berukuran sangat kecil memiliki kualitas opini auditor yang baik. Apabila auditor yang memberikan opini audit wajar tanpa pengecualian kepada suatu perusahaan, menandakan bahwa laporan keuangan telah disajikan secara wajar dan terhindar dari segala macam kesalahan material. Sehingga laporan keuangan akan memenuhi karakteristik andal dan reliable (Ikatan Akuntan Indonesia, 2001). Hal ini dibuktikan dengan skor QAOR yang cukup tinggi yaitu sebesar 75 .

Tidak hanya itu, skor AFR yang dihasilkan juga sangat tinggi sebesar 100.Apabila fee audit yang semakin tinggi maka,akan meningkatkan kualitas audit. Karena semakin luas prosedur audit yang dilakukan oleh auditor sehingga hasil audit akan akurat dan dipercaya (Chrisdinawidanty, Tugiman, \& Mushlih, 2016) dan auditor dapat dengan lebih mendalam dan luas dalam melakukan pendeteksian kejanggalan yang ada dilaporan keuangan.Berdasarkan dari penjelasan diatas dan tingginya skor dari aspek kualitas opini auditor sertafee auditor, secara bersamaan kualitas laporan keuangan juga akan naik.

Sedangkan kelompok perusahaan yang menduduki peringkat terakhir dalam penilaian kualitas laporan keuangan ialah kelompok perusahaan berukuran kecil dengan skor FRQI (Financial Reporting Quality Index) sebesar 42.Hal ini dikarenakan kualitas opini auditor dari kelompok perusahaan berukuran kecil sangat rendah dilihat dari skorQAOR sebesar 0. Ketika auditor yang mengeluarkan opini selain wajar tanpa pengecualian, maka laporan keuangan disajikan secara wajar dengan pengecualian atau disajikan secara tidak wajar.Auditor juga tidak puas dengan seluruh penyajian laporan keuangan sehingga auditor menolak memberikan pendapat.Laporan keuangan tidak terbebas darikesalahan material dan tidak mengikuti GAAP.

Disisi lain, kelompok perusahaan berukuran kecil hanya sebagian yang diaudit oleh KAP Non-Big Four(Skor NBAR sebesar 21). KAP Non-Big Fourkurang memicu klien untuk mengungkapkan keuntungan dan kerugian tepat pada waktunya dan kurang membatasi agresivitas laporan keuangan.Apabila laporan keuangan memiliki kualitas opini auditor rendah dan tingginya agresivitas maka, laporan keuangan kurang berkualitas.

Kelompok perusahaan berukuran keciljuga terindikasi adanya manajemen laba untuk mencapai tujuan tertentu.Manajemen laba dilakukan melalui penghilangan penurunan laba (skor PDAR sebesar 47) dan akrual yang mencerminkan agresivitas laporan keuangan tinggi (skor AR sebesar 48).Perusahaan yang terindikasi ada manajemen laba maka,laporan keuangan yang dihasilkan tidak memenuhi syarat reliable yang mengandung kesalahan materi, menyesatkan, tidak dapat diandalkan dan penyajian tidak jujur, (Ikatan Akuntan Indonesia, 2001),sehingga kualitas laporan keuangan akan menurun.

Jika kualitas laporan keuangan menurun, dampaknyaakan memberikan asimetri informasi serta kesalahan persepsi bagi pemakai laporan keuangan (Kamila, 2014)yangmenyebabkan kesalahan dalam pengambilan keputusan ekonomis dan daya saing secara internasional menurun (Chen, Hope, Li, \& Wang, 2011) dan (Biddle, Hilary, \& Verdi, 2009).

Dari hasil analisis diatas kelompok perusahaan berukuran sangat kecil mengurangi tingkat manajemen laba dikarenakan kelompok perusahaan sangat kecil akan mudah terdeteksi oleh auditor apabila melakukan kecurangan. Ukuran perusahaan yang sangat kecil akan memudahkan dan memungkinkan auditor untuk memeriksa keseluruhan asset, kewajiban, modal 
dan serta aktifitas yang terkait dengan bisnis. Kelompok perusahaan sangat kecil jarang diaudit oleh KAP Big-Four karena biaya audit KAP Big-Four akan jauh lebih mahal dari pada biaya audit KAP Non-Big Four. Jelas dikarenakan auditor Big-Four lebih independen, memiliki pengalaman dan keahlian lebih baik dibanding KAP Non-Big Four (Carcello \& Nagy, 2003).

Selain itu kelompok perusahaan sangat kecil memilihi AFR (Audit Fee Ratio)/ fee audit yang sangat tinggi dikarenakan sistem akuntansi kurang stabil, sehingga audior akan membutuhkan waktu lebih dalam mengaudit laporan Keuangan dan biaya auditor akan tinggi karena besaran tarif imbalan jasa standart per-jam untuk masing-masing tingkatan staff auditor (IAPI, 2016). Hal ini berbanding terbalik dengan perusahaan sangat besar yang telah memiliki sistem akuntansi yang baik dan stabil sehingga memudahkan pekerjaan auditor dan menurunkan jam kerja auditor.

Namun, justru kelompok perusahaan berukuran kecil melakukan tindak manajemen laba guna untuk menyajikan laporan keuangan yang baik untuk investor, sehingga akan menarik investor untuk berinvestasi pada perusahaannya. Apabila banyak investor yang berinvestasi pada perusahaannya memungkinkan kelompok perusahaan yang kecil akan mengembangkan usahanya menjadi lebih besar lagi dan mempertahankan going-corncern perusahaannya.Karena, auditor lebih sering menyatakan opini audit going concern pada perusahaan kecil. Auditor menyatakan bahwa perusahaan besar dapat menyelesaikan kesulitan-kesulitan keuangan yang dihadapi dibanding perusahaan kecil (Mutchler, 1985), sehingga skor QAOR rendah.

Kelompok perusahaan kecil juga jarang diaudit oleh KAP Big Four dikarenakan biaya audit KAP Big-Four akan jauh lebih mahal dari pada biaya audit KAP Non-Big Four. Jelas dikarenakan auditor Big-Four lebih independen, memiliki pengalaman dan keahlian lebih baik dibanding KAP Non-Big Four (Carcello \& Nagy, 2003). Selain itu kelompok perusahaan kecil memiliki AFR (Audit Fee Ratio)/ fee audit yang cukup tinggi dikarenakan sistem akuntansi kurang stabil, sehingga audior akan membutuhkan waktu lebih dalam mengaudit Laporan Keuangan dan biaya auditor akan tinggi karena besaran tarif imbalan jasa standart per-jam untuk masing-masing tingkatan staff auditor (IAPI, 2016).

\section{Kualitas Laporan Keuangan Berdasarkan Umur Perusahaan}

Hasil perhitungan rasio-rasio dan FRQI yang telah dilakukan berdasarkan kategori umur perusahaan, peringkat pertama diduduki oleh kelompok perusahaan berumur menengah dengan skor FRQI sebesar 78.Disusul oleh kelompok perusahaan beumur sangat tua dengan skor FRQI sebesar 50.Kelompok perusahaan beumur sangat muda menduduki peringkat ketiga dengan skor FRQI sebesar 39.Selanjutnya, peringkat keempat diduduki oleh kelompok perusahaan berumur muda dengan skor FRQI sebesar 37.Peringkat terakhir diduduki oleh kelompok perusahaan berumur tua dengan skor FRQI sebesar 28. Hasil perhitungan disajikan dalam Tabel5:

Tabel4.Indeks Kualitas Laporan Keuangan Berdasarkan Umur Perusahaan

\begin{tabular}{lccccc}
\hline & \multicolumn{5}{c}{ Umur Perusahaan } \\
\cline { 3 - 6 } Jumlah Perusahaan & $\begin{array}{c}\text { Sangat } \\
\text { Muda }\end{array}$ & Muda & Menengah & Tua & Sangat Tua \\
\cline { 2 - 6 } & $\mathbf{8 3}$ & $\mathbf{7 8}$ & $\mathbf{7 6}$ & $\mathbf{7 1}$ & $\mathbf{8 0}$ \\
\hline Panel 1. Perhitungan FRQI berdasarkan umur perusahaan \\
Nilai
\end{tabular}



AFR
0,0015
0,0016
0,0013
0,0013
0,0013

LAR

PDAR

AR

QAOR

NBAR

AFR

FRQI

$\begin{array}{ccc}96 & 75 & 100 \\ 42 & 32 & 100 \\ 0 & 0 & 100 \\ 26 & 16 & 96 \\ 23 & 0 & 7 \\ 50 & 100 & 0 \\ \mathbf{3 9} & \mathbf{3 7} & \mathbf{7}\end{array}$

\begin{tabular}{ccc}
100 & 0 & 96 \\
100 & 88 & 0 \\
100 & 42 & 3 \\
96 & 0 & 100 \\
72 & 38 & 100 \\
0 & 0 & 0 \\
$\mathbf{7 8}$ & $\mathbf{2 8}$ & $\mathbf{5 0}$ \\
\hline
\end{tabular}

Panel 2. Jumlah perusahaan berdasarkan elemen FRQI

LAR

Rugi Kecil

Laba Kecil

Non Kategori

4
6
73

\section{3}

67

67

\begin{abstract}
2
\end{abstract}
Kenaikan laba kecil

Non Kategori

QAOR

Wajar Tanpa Pengecualian

Wajar Dengan Pengecualian

Tidak Menyatakan Pendapat

Tidak Wajar

NBAR

Big-Four

Non Big-Four
6

70

$\begin{array}{lc}3 & 2 \\ 8 & 6 \\ 72 & 70\end{array}$

$81 \quad 76$

2

0

0

76
1
1
0

76
1
1
0

$\begin{array}{ll}31 & 25 \\ 52 & 53\end{array}$

$\begin{array}{ccc}4 & 1 & 2 \\ 5 & 7 & 3 \\ 67 & 63 & 75\end{array}$

75

\begin{tabular}{ccc}
6 & 5 & 3 \\
5 & 6 & 12 \\
65 & 60 & 65 \\
75 & 69 & 79 \\
0 & 2 & 1 \\
1 & 0 & 0 \\
0 & 0 & 0 \\
37 & 29 & 44 \\
39 & 42 & 36 \\
\hline
\end{tabular}

Sumber : data penelitian (2018)

Berdasarkan hasil perhitungan Tabel 5 diatas, peringkat pertama dari penilaian kualitas laporan keuangan kategori umur perusahaan diduduki oleh kelompok perusahaan berumur menengah.Dibuktikan dengan skor FRQI (Financal Reporting Quality Index) bernilai paling tinggi, yaitu sebesar 78. Hal ini disebabkan karena adanya indikasi manajemen laba sangat rendah.

Indikasi rendah atau tingginya manajemen laba tercermin dari perhitungan skor LAR yang memiliki skor tertinggi yaitu 100.Artinya, rendahnya tindak penghindaran kerugian yang dilakukan oleh kelompok perusahaan berumur menengah sebagai salah satu indikasi manajemen laba.Selain rendahnya penghindaran kerugian, skor PDAR tertinggi yaitu 100, mengindikasikan bahwa penghilangan penurunan laba yang rendah sebagai salah satu bentuk rendahnya manajemen laba.

Selain itu, nilai akrual dari kelompok perusahaan berumur menengah rendah (skor AR sebesar 100).Tinggi rendahnya akrual digunakan untuk mengukur perilaku agresif laporan keuangan (Tang, Chen, \& Lin, 2016). Akrual yang rendah berarti bahwa tingkat agresivitas laporan keuangan rendah.Apabila tingkat akrual dan manajemen laba semakin rendah, maka akan diikuti dengan meningkatnya kualitas laporan keuangan yang mengakibatkan daya saing efisiensi investasi secara internasional naik pula (Chen, Hope, Li, \& Wang, 2011) dan (Biddle, Hilary, \& Verdi, 2009).

Kelompok perusahaan berumur menengah kebanyakan diaudit oleh KAP Big-Four (skor NBAR sebesar 72). KAP Big-Four yangpada umumnya dianggap independen, karena memiliki pengalaman dan keahlian yang lebih baik dari pada KAP Non-Big Four (Carcello \& Nagy, 2003)yangdapat lebih memicu klien untuk mengungkapkan keuntungan dan kerugian tepat pada waktunya dan membatasi agresivitas laporan keuangan. 
SkorQAORyang mencerminkan kualitas opini audit yang dihasilkan sebesar 96. Apabila auditor yang memberikan opini audit wajar tanpa pengecualian maka laporan keuangan telah disajikan secara wajar dan terhindar dari segala macam kesalahan material, sehingga laporan keuangan akan memenuhi karakteristik andal dan reliable (Ikatan Akuntan Indonesia, 2001). Jika laporan keuangan terbebas dari agresivitas pelaporan, terbebas dari segala kesalahan yang material dan telah diaudit secara menyeluruh dan substantif maka kualitas laporan keuangan tersebut akan naik.

Sedangkan, peringkat terakhir dari penilaian kualitas laporan keuangan berdasarkan kategori umur perusahaan jatuh kepadakelompok perusahaan berumur tua yang memiliki FRQI (Financial Reporting Quality Index) sebesar 28.Hal ini dikarenakan kualitas opini auditor dari kelompok perusahaan berumur tua sangat rendah dilihat dari skor QAOR sebesar 0 .

Apabila opini yang dikeluarkan auditor selain wajar tanpa pengecualian, maka laporan keuangan disajikan secara wajar dengan pengecualian, atau disajikan secara tidak wajar.Auditor juga tidak puas dengan seluruh penyajian laporan keuangan sehingga auditor menolak memberikan pendapat.Sehingga laporan keuangan tidak terbebas darikesalahan material dan tidak mengikuti GAAP.

Kelompok perusahaan berumur tua sebagian besar diaudit oleh KAP Non-Big Four (Skor NBAR sebesar 38).KAP Non-Big Four kurang memicu klien untuk mengungkapkan keuntungan dan kerugian tepat pada waktunya dan kurang membatasi agresivitas laporan keuangan.Selain itu skor AFR yang rendah sebesar 0 , juga mempengaruhi auditor dalam melaksanakan prosedur audit.Fee audit yang rendah akan memberikan batasan prosedur audit dikarenakan kurangnya biaya audit. Oleh karena ada batasan prosedur dan laporan keuangan disajikan ada kesalahan material dan tidak mengikuti GAAP.Apabila laporan keuangan memiliki kualitas opini auditor rendah, tidak terbebas dari salah saji material dan tingginya agresivitas maka, laporan keuangan kurang berkualitas.

Kelompok perusahaan berumur tua juga terindikasi adanya manajemen laba untuk mencapai tujuan tertentu.Manajemen laba dilakukan melalui penghindaran kerugian (skor LAR sebesar 0) dan akrual yang mencerminkan agresivitas laporan keuangan tinggi (skor AR sebesar 42). Apabila perusahaan terindikasi adanya manajemen laba maka laporan keuangan tidak memenuhi syarat reliable yang mengandung kesalahan materi, menyesatkan, tidak dapat diandalkan dan penyajian tidak jujur, (Ikatan Akuntan Indonesia, 2001), sehingga kualitas laporan keuangan akan menurun.

Jika kualitas laporan keuangan menurun, dampaknya akan memberikan asimetri informasi serta kesalahan persepsi bagi pemakai laporan keuangan (Kamila, 2014)yang menyebabkan kesalahan dalam pengambilan keputusan ekonomis dan daya saing secara internasional menurun (Chen, Hope, Li, \& Wang, 2011) dan (Biddle, Hilary, \& Verdi, 2009).

Berdasarkan analisis diatas, kelompok perusahaan berumur menengah yaitu perusahaan yang sedang berada pada tahap kedewasaan (mature). Tahap mature ini ialah tahap dimana manajemen telah mulai pofesional (Schori \& Garee, 1998). Manajemen yang profesional akan menghasilkanlaporan keuangan berkualitas yang terbebas dari manajemen laba dan memiliki kualitas audit yang baik sehingga skorFRQI menjadi tinggi.

Sedangkan, untuk kelompok perusahaan beumur tua merupakan perusahaan yang sedang berada pada tahap akhir dari siklus umur perusahaan yaitu decline.Pada tahap decline,perusahaan akan digambarkan seperti manusia berusia lanjut. Perusahaan akan mengalami penurunan yang signifikan, atau kemungkinan terburuk apabila tidak dapat bertahan perusahaan akan 
meninggalkan bisnisnya (Schori \& Garee, 1998). Oleh sebab itu FRQI yang dihasilkan sangatlah rendah dan mempengaruhi laporan keuangan menjadi tidak berkualitas.

Namun, ada beberapa perusahaan yang mampu bertahan serta melewati tahap declinedan masih pada kondisi yang stabil (stagnant).Perusahaan tersebut mengalami penururnan laba yang cukup drastis dikarenakan penjualan tidak begitu mengalami peningkatan (Anthony \& Ramesh, 1992).Perusahaan yang sangat tua ini sudah memiliki manajemen yang professional, lebih mapan dan mulai membenahi perusahaannya kembali sehingga menghasilkan FRQI yang berada pada tengah tengah antara baik dan buruk yaitu sebesar 50 .

\section{Kualitas Laporan Keuangan Berdasarkan Jenis Industri}

Hasil perhitungan rasio-rasio dan FRQI yang telah dilakukan berdasarkan kategori jenis industri, peringkat pertama diduduki oleh kelompok industri manufaktur dengan skor FRQI sebesar 63.Selisih tipis satu poin dengan kelompok industri manufaktur, peringkat kedua diduduki oleh kelompok industri jasa dengan skor FRQI sebesar 62. Dan yang terakhir, peringkat ketiga diduduki oleh kelompok industri sektor utama dengan skor FRQI sebesar 31. Hasil perhitungan disajikan dalam Tabel 6 dibawah ini:

Table 5. Indeks kualitas laporan keuangan berdasarkan industri perusahaan

\begin{tabular}{|c|c|c|c|c|}
\hline & & \multicolumn{3}{|c|}{ Jenis Industri } \\
\hline & & Manufaktur & Jasa & Sektor utama \\
\hline \multicolumn{2}{|c|}{ Jumlah Perusahaan } & 111 & 217 & 60 \\
\hline \multicolumn{5}{|c|}{ Panel 1. Perhitungan FRQI berdasarkan jenis industri } \\
\hline & LAR & 1,8000 & 2,1429 & 2,5000 \\
\hline & PDAR & 4,0000 & 1,4667 & 3,0000 \\
\hline & AR & $(0,0031)$ & $(0,0155)$ & $(0,0712)$ \\
\hline & QAOR & 0,0180 & 0,0138 & 0,0500 \\
\hline & NBAR & 0,5315 & 0,5945 & 0,5667 \\
\hline & AFR & 0,0013 & 0,0012 & 0,0022 \\
\hline \multicolumn{5}{|c|}{ Nilai Indeks } \\
\hline & LAR & 100 & 51 & 0 \\
\hline & PDAR & 0 & 100 & 39 \\
\hline & AR & 0 & 18 & 100 \\
\hline & QAOR & 88 & 100 & 0 \\
\hline & NBAR & 100 & 0 & 44 \\
\hline & AFR & 91 & 100 & 0 \\
\hline & FRQI & 63 & 62 & 31 \\
\hline \multicolumn{5}{|c|}{$\begin{array}{l}\text { Panel 2. Jumlah perusahaan berdasarkan elemen FRQI } \\
\text { LAR }\end{array}$} \\
\hline & Rugi Kecil & 5 & 7 & 2 \\
\hline & Laba Kecil & 9 & 15 & 5 \\
\hline & Non Kategori & 97 & 195 & 53 \\
\hline \multicolumn{5}{|l|}{ PDAR } \\
\hline & Penurunan Laba Kecil & 3 & 15 & 1 \\
\hline & Kenaikan laba kecil & 12 & 22 & 3 \\
\hline & Non Kategori & 96 & 180 & 56 \\
\hline \multicolumn{5}{|l|}{ QAOR } \\
\hline & Wajar Tanpa Pengecualian & 109 & 214 & 60 \\
\hline & Wajar Dengan Pengecualian & 2 & 2 & 2 \\
\hline & Tidak Menyatakan Pendapat & 0 & 1 & 1 \\
\hline & Tidak Wajar & 0 & 0 & 0 \\
\hline
\end{tabular}




\begin{tabular}{lccc} 
Big-Four & 52 & 88 & 26 \\
Non Big-Four & 59 & 129 & 34 \\
\hline
\end{tabular}

Sumber : data penelitian (2018)

Berdasarkan hasil perhitungan Tabel 6 diatas, peringkat pertama dari penilaian kualitas laporan keuangan kategori jenis industri diduduki oleh kelompok industri manufaktur.Dibuktikan dengan nilai FRQI (Financal Reporting Quality Index) yang bernilai paling tinggi, sebesar 63. Hal ini dikarenakan indikasi adanya manajemen laba rendah.

Indikasi rendah atau tingginya manajemen laba tercermin dari perhitungan skor LAR yang memiliki nilai tertinggi yaitu 100.Artinya, rendahnya tindak penghindaran kerugian yang dilakukan oleh kelompok industri manufaktur sebagai salah satu indikasi manajemen laba. Apabila tingkat manajemen laba semakin rendah, maka akan diikuti dengan meningkatnya kualitas laporan keuangan yang mengakibatkan daya saing efisiensi investasi secara internasional naik pula (Chen, Hope, Li, \& Wang, 2011) dan (Biddle, Hilary, \& Verdi, 2009)

Kelompok industri manufaktur ini kebanyakan diaudit oleh KAP Big-Four (skor NBAR sebesar 100). KAP Big-Four yangpada umumnya dianggap independen, karena memiliki pengalaman dan keahlian yang lebih baik dari pada KAP Non-Big Four (Carcello \& Nagy, 2003)yangdapat lebih memicu klien untuk mengungkapkan keuntungan dan kerugian tepat pada waktunya dan membatasi agresivitas laporan keuangan.

AFR yang dihasilkan juga cukup tinggi sebesar 91. Apabila fee audit yang semakin tinggi maka, akan meningkatkan kualitas audit. Hal ini karena semakin luas prosedur audit yang dilakukan oleh auditor sehingga hasil audit akan akurat dan dipercaya (Chrisdinawidanty, Tugiman, \& Mushlih, 2016) dan auditor dapat dengan lebih mendalam dan luas dalam melakukan pendeteksian kejanggalan yang ada dilaporan keuangan.

Nilai QAOR yang mencerminkan kualitas opini audit sebesar 88. Apabila auditor yang memberikan opini audit wajar tanpa pengecualian maka laporan keuangan telah disajikan secara wajar dan terhindar dari segala macam kesalahan material, sehingga laporan keuangan akan memenuhi karakteristik andal dan reliable (Ikatan Akuntan Indonesia, 2001). Jika laporan keuangan terbebas dari agresivitas pelaporan, terbebas dari segala kesalahan yang material dan telah diaudit secara menyeluruh dan substantif maka kualitas laporan keuangan tersebut akan naik.

Peringkat kedua dalam penilaian kualitas laporan keuangan disusul oleh kelompok industri jasa dengan skor 62 yang nyaris menyamai skor dari kelompok industri manufaktur.kelompok industri jasa memiliki skor PDAR yang tinggi yaitu sebesar 100, sehingga mengindikasikan bahwa manajemen laba yang rendah. Kualitas audit yang baik pula dicerminkan dari skor QAOR dan AFR sebesar 100. Jika kualitas audit yang baik maka laporan keuangan dapat dipercaya oleh penggunanya. Sehingga mengakibatkan kualitas laporan keuangan naik seiring dengan kenaikan kulitas audit.

Terakhir, kelompok perusahaan yang menduduki peringkat ketiga dalam penilaian kualitas laporan keuangan kategori jenis industri ialah kelompok industri sektor utama yang memiliki FRQI (Financial Reporting Quality Index) sebesar 31.Hal ini dikarenakan kualitas opini auditor dari kelompok industri sektor utama sangat rendah dilihat dari skor QAOR sebesar 0 .

Apabila auditor mengeluarkan opini selain wajar tanpa pengecualian, maka laporan keuangan disajikan secara wajar dengan pengecualian, atau disajikan secara tidak wajar.Auditor juga tidak puas dengan seluruh penyajian laporan keuangan sehingga auditor menolak memberikan pendapat.Selain itu, skor AFR yang rendah sebesar 0 juga mempengaruhi auditor 
dalam melaksanakan prosedur audit.Fee audit yang rendah akan memberikan batasan prosedur audit dikarenakan kurangnya biaya audit.Oleh karena ada batasan prosedur dan laporan keuangan disajikan ada kesalahan material dan tidak mengikuti GAAP menyebabkan kualitas laporan keuangan turun.

Kelompok industri sektor utama, juga terindikasi adanya manajemen laba untuk mencapai tujuan tertentu.Manajemen laba dilakukan melalui penghilangan penurunan laba (skor PDAR sebesar 39) dan penghindaran kerugian (skor LAR sebesar0). Apabila perusahaan terindikasi adanya manajemen laba maka laporan keuangan tidak memenuhi syarat reliable yang mengandung kesalahan materi, menyesatkan, tidak dapat diandalkan dan penyajian tidak jujur, (Ikatan Akuntan Indonesia, 2001) sehingga kualitas laporan keuangan akan menurun.

Jika kualitas laporan keuangan menurun, dampaknya akan memberikan asimetri informasi serta kesalahan persepsi bagi pemakai laporan keuangan (Kamila, 2014) sehingga menyebabkan kesalahan dalam pengambilan keputusan ekonomis dan daya saing secara internasional menurun (Chen, Hope, Li, \& Wang, 2011) dan (Biddle, Hilary, \& Verdi, 2009).

Dari hasil analisis diatas, dapat dilihat bahwa jenis industri manufaktur dan jasayang menghasilkan nilai FRQI hampir sama dan hanya memiliki selisih tipis 1 point. Hal ini disebabkan karena pada sektor jasa dan manufaktur yang memiliki persaingan pasar yang sangat ketat.Sehingga dalam sektor jasa dan manufaktur lebih mengembangkan intellectual capital (modal intelektual) seperti halnya mengembangkan sumberdaya non-tangible atau tangible physical yang mencakup kapasitas inovasi, pola, proses, dan pengetahuan.

Sumberdaya intangible tersebut dikombinasikan dengan kegiatan yang mentransfromasi bundelan keuangan, material dan sumberdaya manusia kedalam kecakapan sistem untuk menciptakan stakeholder value(Zurnali, 2010).Sistem yang baik didukung oleh modal manusia (human capital) yang bernilai tinggi untuk mengaplikasikan keterampilan dan keahlian anggota sehingga menjadi lebih efektif dalam pekerjaannya.Selain human capital, aspek modal struktural (Structural Capital) juga sangat penting dalam melahirkan sistem yang baik. Tidak melulu mengenai gedung, perangkat keras dan lunak, akan tetapi structural capital juga meliputi proses, intangible assets, citra organisasi, sistem informasi dan hak milik basis data.

Sejalan dengan pembangunansistem yang baik, sistem akuntansi juga akan baik dan melahirkan laporan keuangan yang berkualitas untuk kepentingan investor, kreditur, dan pengguna laporan keuangan guna mengembangkan modal relasional (relational capial) seperti waralaba, interaksi antar pelanggan dan pemasok serta untuk menghadapi persaingan pasar pada sektor tersebut.

Sedangkan dalam jenis industri sektor utama memiliki nilai FRQI rendah sebesar 31, menandakan kualitas laporan keuangan pada sektor utama kurang bekualitas.Hal ini disebabkan karena pada sektor utama sering mengabaikan intellectual capital (modal intelektual).Dalam sektor utama tidak begitu melakukan persaingan yang ketat antar perusahaan sesama sektor yang telah memiliki pasar tersendiri.

\section{Simpulan}

\section{PENUTUP}

Berdasarkan pembahasan yang telah dilakukan diatas dapat ditarik kesimpulan sebagai berikut : Dari kategori ukuran, justru kelompok perusahaan berukuran sangat kecil yang memiliki kualitas laporan keuangan paling tinggi. Sedangkan kelompok perusahaan berukuran kecil memiliki kualitas laporan keuangan paling rendah. Dari kategori umur, kelompok perusahaan berumur menengah memiliki kualitas laporan keuangan paling tinggi. Sedangkan 
kelompok perusahaan berumur tua memiliki kualitas laporan keuangan paling rendah. Dari kategori jenis industri, kelompok industri manufaktur memiliki kualitas laporan keuangan paling tinggi. Kemudian disusul oleh kelompok industri jasa yang hanya memiliki selisih satu point dengan kelompok industri manufaktur. Kualitas laporan keuangan terendah diduduki oleh kelompok industri sektor utama. Laporan keuangan yang memiliki kualitas yang tinggi ialah laporan keuangan yang terbebas dari manajemen laba, terbebas dari salah saji material dan memiliki kualitas audit yang tinggi dari auditor. Sedangkan, laporan keuangan yang memiliki kualitas yang rendah merupakan laporan keuangan yang mengandung manajemen laba, tidak terbebas dari salah saji material dan memiliki kualitas audit yang rendah.

\section{Implikasi}

Penelitian ini dapat digunakan sebagai acuan bagi pembaca/pengguna laporan keuangan dan investor ketika akan melakukan keputusan ekonomis. Dari hasil diatas, akan lebih baik pengguna laporan keuangan melakukan kegiatan ekonomis pada perusahaan yang memiliki kualitas laporan keuangan tinggi yaitu kelompok perusahaan berukuran sangat kecil, kelompok perusahaan berumur menengah dan kelompok perusahaan industri manufaktur dibandingkan dengan kelompok perusahaan yang memiliki ukuran, umur dan jenis industri lain. Karena, laporan keuangan berkualitas tinggi akan terbebas dari manajemen laba yang mengaburkan informasi bagi pengguna sehingga laporan disajikan sesuai dengan kondisi perusahaan, dan apabila laporan keuangan memiliki kualitas audit yang baik berarti laporan keuangan dapat dipercaya oleh pengguna.

Selain itu, berbeda dari penelitian sebelumnya yang menilai laporan keuangan secara parsial dari aspek relevansi, konservatisme dan ketepatan waktu. Penelitian ini menilai kualitas laporan keuangan secara komprehensif menggunakan indeks terbaru yang sudah mengakomodasi berbagai elemen pelaporan keuangan seperti perhitungan manajemen laba, tingkat agresitivitas pelaporan keuangan dan kualitas audit. Penelitian ini juga dinilai berdasarkan kategori umur, ukuran dan jenis industri perusahaan go public yang berada di Indonesia.

\section{Keterbatasan dan Saran}

Keterbatasan penelitian ini yang dapat dipertimbangkan untuk agenda penelitian selanjutnya yaitu penelitian ini tidak dapat meneliti/menilai kualitas laporan keuangan sektor usaha finance dan perusahaan tertutup. Maka diharapkan untuk penelitian selanjutnya dapat meneliti kualitas laporan keuangan pada sektor usaha finance dan perusahaan tertutup.

\section{Daftar Pustaka}

Agoes, Sukrisno. 2012. Auditing Petunjuk Praktis Pemeriksaan Akuntan Oleh Akuntan Publik. Jilid 1, Edisi Keempat. Jakarta : Salemba Empat.

Anthony, J. H., \& Ramesh, K. 1992 Association between Accounting Performance Measures and Stock Prices: A Test of the Life Cycle Hypothesis. Journal of Accounting and Economics. 15: 203-227.

Ardiyos. 2007. Kamus Standar Akuntansi. Jakarta : Citra Harta Prima Andayani,

Barth, M.E., Beaver, W.H., Hand, J.R.M. and Landsman, W.R. 1999a Accruals, cash flows, and equity value. Review of Accounting Studies. 4(3): 205-229.

Barth, M.E., Elliott, J.A. and Finn, M.W. 1999b Market rewards associated with patterns of increasing earnings. Journal of Accounting Research. 37(2): 387-413. 
Bartov, E. 1993 The Timing of Asset Sales and Earnings Manipulation. The Accounting Review. Vol. 68 (4): 840-855.

Biddle Gary. Hilary. dan Verdi. 2009. How does financial reporting quality relate to investment efficiency?. Journal of Accounting and Economics. 48 (2-3): 112-131

Carcello, J. and Nagy, A. 2003 Auditor industry specialization and fraudulent financial reporting. Working Paper, University of Tennessee. John Carroll University.

Chen, F., Hope, O.-K., Li, Q. and Wang, X. 2011 Financial reporting quality and investment efficiency of private firms in emerging markets. The Accounting Review. 86(4): 12551288.

Chrisdinawidanty, Z. N., Tugiman, H., \& Mushlih, M. 2016. Pengaruh Etika Auditor Dan Fee Auditor Terhadap Kualitas Audit (Studi Kasus Pada Kantor Akuntansi Publik Diwilayah Bandung). e-Proceeding of Management. 3(3): 3466-3474.

DeAngelo, H., DeAngelo, L., \& Skinner, D. 1996 Reversal of Fortune: Dividend Signaling and The Disappearance of Sustained earnings Growth. Journal of Financial Economic. 40(3): 341-371.

DeANGELO, L. E. 1981 Auditor Size and Auditor Quality. Journal of Accounting and Economics. 3: 183-199.

Dopuch, N., Holthausen, R., \& Leftwich, R. 1986 Abnormal Stock Returns Associated With Media Disclosures of 'Subject To' Qualified Audit Opinions. Journal of Accounting and Economics. 2: 93-117.

Fanani, Z. 2009. Kualitas Pelaporan Keuangan: Berbagai Faktor Penentu Dan Konsekuensi Ekonomis. Jurnal Akuntansi dan Keuangan Indonesia. 6(1): 20-45.

Frank, M. M., Lynch, L. J., \& Sonja, O. R. 2009. Tax Reporting Aggressiveness and its Relation to Aggressive Financial Reporting. Accounting Review. 84(2): 1-49.

Hanif, R. A., \& Putri, E. 2014. Audit Fee, Jasa Selain Audit, Profil Kantor Akuntan Publlik, Lamanya Hubungan Audit Dengan Klien Terhadap Independensi Akuntan Publik Di Pekanbaru Dan Medan. Junal Ekonomi. (22)3: 154-167.

Healy, P. M., \& Wahlen, J. M. 1999. A Review of the Earnings Management Lilterature and Its Implications for Standard Setting. Accounting Horizons. 13(4): 356-383.

Hendriksen, E. S. 2000. Teori Akuntansi. Jakarta: Erlangga.

Herawaty, B. 2011. Pengaruh Pengendalian Intern Dan Lamanya Waktu Audit terhadapp Fee Audit (Studi Kasus Pada KAP Jambi Dan Pelembang). Jurnal Penelitian Universitas Jambi Sri Humaniora. 13(1): 07-12.

IAI. 2009. Kerangka Dasar Penyusunan Penyajian Laporan Keuangan. jakarta: Ikatan.

IAPI. 2016. Peraturan Pengurus Nomor 2 Tahun 2016 Tentang Penentuan Imbalan Jasa Audit Laporan Keuangan. Institut Akuntan Publik Indonesia.

Ikatan Akuntan Indonesia. 2001. Standart Profesional Akuntan Publik. Jakarta: Salemba Empat.

Ikatan Akuntansi Indonesia. 2011. Standart Akuntansi Keuangan Publik. Jakarta: Salemba Empat.

Indriani, P., Darmawan, J., \& Nurhawa, S. 2014. Analisis Manajemen laba Terhadap Nilai Perusahaan yang Terdaftar di Bursa Efek Indonesia. Jurnal Akuntansi \& Keuangan. 5(1): 19-31.

Kamila, P. A. 2014. Analisis Hubungan Agresivitas Pelaporan Keuangan dan Agresivitas Pajak. Finance and Banking Journal 16(2): 228-245.

Kovinna, F., \& Betri. 2010. Pengaruh Independensi, Pengalaman Kerja, Kompetensi Dan Etika Auditor Terhadap Kualitas Audit. STIE MDP. 
Kurniasih, M., \& Rohman, A. 2014. Pengaruh Fee Audit, Audit Tenure, Dan Rotasi Audit Terhadap Kualitas Audit. Diponegoro Journal of Accounting. 3(3).

Kusumawardani, D., \& Riduwan, A. 2017. Pengaruh Independensi, Audit Fee, Dan Objektivitas Terhadap Kualitas Audit. Jurnal Ilmu dan Riset Akuntansi. 6(1): 389-402.

Mulyadi. 2009. Auditing. Jakarta: Salemba Empat.

Mutchler, J. 1985. A Multivariate-Analysis Of The Auditors Going-Concern Opinion Desecion. Journal of Accounting Research. 23(2): 668-682.

Nariman, A. 2015. Pengaruh Ukuran Kantor Akuntan Publik Terhadap Opini Going Concern Dan Earnings Response COefficients (ERC) Pada Perusahaan Manufaktur Yang Terdaftar Di BEI Tahun 2011-2013. Jurnal Akuntansi XIX(02): 160-178.

PSAK No.1 Revisi. 2009. Standar Akuntansi Keuangan. Jakarta: Salemba Empat.

Rusmanto. 2008. Pengaruh Karakteristik Kualitatif Laporan Keuangan Terhadap Penggunaanya dalam Pengambilan Keputusan Kredit Bank Umum Banjarmasin. Ekuitas. 12(1): 53-73.

Schipper, K. 1989. Commentary on Earnings Management. Accounting Horizon. 91-102.

Schori, T. R., \& Garee, M. L. 1998. Like Products, Companies have Life Cycle. Marketing Views. 32.

Setiany, e., \& Wulandari, A. 2015. Kualitas Pelaporan Keuangan dan Asimetri Informasi di Industri Manufaktur Indonesia. EFEKTIF Jurnal Bisnis dan Ekonomi. 6(2): 17-24.

Setyawati, L. J. 2015. Kualitas Informasi Pelaporan Keuangan: Faktor- Faktor Penentu Dan Pengaruhnya Terhadap Efisiensi Investasi. Jurnal Ekonomi dan Bisnis. 2: 186-196.

Tang, Q., Chen, H., \& Lin, Z. 2016. How To Measure Country-Level Financial Reporting Quality?. Journal of Financial Reporting and Accounting. 14(2): 230-265.

Tobing, R., \& Nirwana. 2004. Kamus Istilah Akuntansi. Jakarta: Atalya Rileni Sucedo.

Watkins, A. L., Hilson, W., \& Morecroft, S. 2005. Audit Quality : A Synthesis of Theory and Empirical Evidence. Journal of Accounting Literature. 23.

Wicaksono, A. B., \& Yuyetta, E. N. 2013. Pengaruh Kecakapan Manajerial Terhadap Praktik Manajemen Laba Dengan Corporate Governance Sebagai Variabel Pemoderasi. Diponegoro Journal Of Accounting. 2(4): 1.

Yuyetta, A. B. 2013. Pengaruh Kecakapan Manajerial Terhadap Praktik Manajemen Laba Dengan Corporate Governance Sebagai Variabel Pemoderasi. Diponegoro Journal Of Accounting. 2(40): 1.

Zurnali, C. 2010. Learning Organizaion, Competency, Organizational Commitment, And Customer Orientation: Knowledge Worker-Kerangka riset Manajemen Sumber Daya Manusia Masa Depan. Unpad Press. 